\title{
Integrated water resource and flood risk management: comparing the US and the EU
}

\author{
Anna Serra-Llobet ${ }^{1, a}$, Esther Conrad ${ }^{2}$, Kathleen Schaefer ${ }^{3}$ \\ ${ }^{1}$ Institute of International Studies, University of California, Berkeley, 215 Moses Hall, Berkeley, California 94720, US \\ ${ }^{2}$ Gould Center for Conflict Resolution, Stanford Law School, and the Water in the West Program, Woods Institute for the Environment, \\ Stanford University, US \\ ${ }^{3}$ Center for Catastrophic Risk Management, University of California, Berkeley, $8^{\text {th }}$ Floor Barrows Hall, Berkeley, California 94720, US
}

\begin{abstract}
Floods are the most important natural hazard in the EU and US, causing 700 deaths and at least $€ 25$ billion in insured economic losses in Europe since 1998, and causing nearly $\$ 10$ billion annual average flood losses in the US. Flood control is commonly viewed as a matter of building dykes, dams, and other structures, but effective flood management within the perspective of Integrated Water Resource Management (IWRM) must address multiple components of the flood risk management cycle (Figure 1). We systematically reviewed governance structures, guidance documents, and mapping products in both the EU and US, drawing particular examples from California and Spain, to determine how the US and the EU approach the flood risk management within different IWRM initiatives, which strategies and agencies are involved in the different phases -characterization (flood hazard and risk assessment and mapping), mitigation (prevention and protection), emergency (preparation and response), and (short and long term) recovery-, and how these agencies relate to each other. The regions have strong similarities in economy and environmental values, but have evolved very different approaches to cope with floods. The US and EU have similar organizational structures, but very different legislative frameworks. In the US overarching policy and large scale infrastructure funding have traditionally resided at the federal level with state and local agencies exercising strong land use control. EU member states have arguably advanced ahead of the US in some significant ways since adoption of the EU Floods Directive in 2007, a more top-down approach. Among the Directive's many components, one important requirement is submission of flood risk management plans (by the end of 2015), which, for first time, take into account all phases of flood management. This umbrella strategy to cope with floods is creating a more consistent and integrated flood risk management approach in Europe. In 2008, the State of California, with over $2500 \mathrm{~km}$ of levees, enacted a comprehensive package of flood management legislation and state bond financing that far exceeds federal and other state's actions. This program known as FloodSafe California provided funding for projects within Integrated Regional Water Management Plans, an attempt to implement IWRM at regional scale. Although the efforts of FloodSafe California represent as a major change in direction in US flood risk management, the actions still do not fully implement the integrated flood risk approach promoted by the EU.
\end{abstract}

\section{Introduction}

Integrated water resources management (IWRM) has gained widespread currency as an approach to managing water sustainably in the face of increasing demands and uncertainties (1,2). As defined by the Global Water Partnership, IWRM is "a process which promotes coordinated development and management of water, land, and related resources in order to maximize economic and social welfare in an equitable manner without compromising the sustainability of vital ecosystems" (3). IWRM is closely intertwined with the concept of river basin planning, which has much older roots. In the $19^{\text {th }}$ century, river basin scale planning was promoted as the best way to maximize human uses of water for

${ }^{\mathrm{a}}$ Corresponding author: annaserrallobet@gmail.com hydropower, water supply, and flood control. This provided a rationale for regional-scale, infrastructurebased projects such as the Tennessee Valley Authority in the United States, which served as a model in many other parts of the world (4). However, as a result of growing attention to the environmental impacts of water infrastructure, the river basin planning concept has taken on new meaning in recent decades. Agenda 21, an action plan for sustainable development that emerged from the 1992 Earth Summit in Rio de Janeiro, called for a focus on "integrated" management at the river basin scale, recognizing all elements of a water system as connected through larger ecological and social processes, and emphasizing that equity and environmental sustainability need to be addressed alongside economic development 
(2). IWRM has since been widely embraced by the water management community worldwide (4). However, as many scholars and practitioners have noted, IWRM is as broad concept that has been interpreted in varying ways, and has often been challenging to put into practice $(1,5)$.

Although IWRM is probably thought of mostly in terms of water supply and water quality, its purview properly includes flood and flood risk management as well. This paper provides an overview of IWRM as attempted in the European Union (EU) and United States (US), with a focus on flood risk management aspects, and then examines in detail implementation of IWRM and component flood risk management actions undertaken in two comparable regions: the Catalan coastal region around Barcelona, Spain, and the San Francisco Bay region around San Francisco, California, US. These two regions have similar climatic and socio-economic characteristics but very different governance structure.

\section{Data and Methods}

We compared IWRM as implemented in the EU under the Water Framework Directive (WFD) and Floods Directive (FD), with various efforts at IWRM at the national level of the US, along with some state and regional efforts. We then focused on IWRM and flood risk management under IWRM, as implemented in Catalonia, Spain, and in the San Francisco Bay region, California (6).

Specifically, we examined the Catalan River Basin District (Water) Management Plan and the Catalan River Basin District Flood Risk Management Plan, both prepared in 2015, and the San Francisco Bay Area Integrated Regional Water Management Plan from 2013. We reviewed governance structures, guidance documents, and mapping products in both the EU and the US, analyzed the IWRM plans for each region, and interviewed staff involved in the development of the plans, to determine how these IWRM plans integrate the flood risk management.

\subsection{IWRM in the EU: The Water Framework Directive and the Floods Directive}

Although the post-Second World War unification process resulted in some European-based directives focused mainly on water quality, the concept of IWRM really appeared in Europe with the adoption of the Water Framework Directive (WFD) in 2000, which represented a radical reform of water legislation in the EU (7).

With the initial goal to achieve good ecological status of all waters by 2015, the WFD required all member states to define River Basin Districts at a EU scale as a new unit of management (Article 3(1)), which are based largely on surface water catchments, together with the boundaries of associated groundwater and coastal water bodies. Under the WFD, water bodies are classified in five status classes: high, good, moderate, poor and bad, taking into account not only the chemical status (prioritary substances) but also the ecological status: physico-chemical, biological and hydromorphological elements.

Under the WFD, competent authorities were to be constituted at the river basin scale to carry out river basin assessments, to identify objectives, and define programmes of measures, such that all river basins should achieve good quality status. The programme of measures was to be iteratively evaluated in updates every 6 years, building on the river basin management plans, first submitted in 2009 and to be improved in subsequent cycles.

While the WFD did not entirely ignore floods, its focus was on water quality and ecological condition. Extensive flooding in Central Europe in 2002 highlighted the need for a comparable directive addressing flood risk management, and in 2007 the EU adopted the Floods Directive (8). The Floods Directive was to be implemented within the framework of the WFD, so that flood risk management plans were to be developed by the same competent authorities already established to develop and implement the River Basin Management Plans. The integration of the flood risk management plans within the WFD framework had profound implications for how flood risk management was to be implemented. For example, the inclusion of hydromophological elements in the definition of good ecological status implied a shift in thinking about managing floods, because conventional structural measures typically result in simplification of channel form, resulting in loss of hydromorphological and ecological quality. Thus, nonstructural measures or soft structural measures for flood risk management, such as land-use controls, and river and floodplain restoration, are favored under the WFD.

Member states presented their second river basin management plan to the EU in 2015. One key improvement over the prior (2009) plans was the requirement that the 2015 river basin plans incorporate flood risk management plans focused on prevention, protection and preparedness, also at a river basin scale, as required by the Floods Directive (8). This plan is based on a preliminary assessment of riverine and coastal areas at risk of flooding, as of 2011. For such zones, flood hazard and risk maps were drawn up in 2013. These maps subsequently served as the cornerstone of the flood risk management plans.

To fund the actions defined through the programme of measures is one of the big challenges of the implementation of the WFD and Floods Directive. The funding for the programme of measures comes from the River Basin authorities and agents involved in the water cycle in the river basin, mainly state, regional and local governments, as well as local users. The EU also offers different possibilities for funding. For example, floodrelated projects can be funded with the LIFE programme, 
through structural and cohesion funds or through the Common Agricultural Policy, which includes agrienvironmental measures as rural development projects, which can contribute to flood related projects. There are other options such as a number of pre-accession funds such as SAPARD or the EU Solidarity Funds for major disasters (9).

\subsection{IWRM in the US: Various National and State- level Initiatives}

The need for IWRM was clearly articulated by federal-level planning efforts, such as those launched by passage of the Water Resources Planning Act of 1965, which created federal-state river basin commissions to improve water resources planning and thereby promote rational economic development, and empowered the President's Water Resources Council (WRC), with membership drawn from various federal entities, to coordinate the river basin commissions and initiate national-level water planning. Among the WRC's accomplishments were release of the first national-scale assessment of water resources (10), and the Principles and Standards for federally-funded water projects and water allocation (1973), which took into account not only the highest economic use but also social values in water and land use. The ideals of comprehensive water resources planning reflected in the 1965 act and in the efforts of the WRC can be traced back to the Eisenhower and Kennedy administrations, and were supported under the Johnson, Nixon, Ford, and Carter administrations, but were cut off by the Reagan administration, which eliminated the WRC and the river basin commissions (11). Although there have since been various voluntary efforts to encourage integrated planning at the river basin scale, such as the US Environmental Protection Agency's watershed $^{\mathrm{a}}$ approach $(12,13)$, since elimination of the WRC in 1981, there has been no comparable national level attempt to implement IWRM in the US.

Federal efforts to coordinate rational management of floodplains ran on a parallel track. The 1965 act included a requirement that the President to report to Congress on a Unified National Program (UNP) for Floodplain Management, and the UNP was presented in 1966, 1979, 1986, and finally in its best-known form, in 1994 (16). The UNP called for non-structural measures as first efforts prior to resorting to structural solutions. In part inspired by the arguments of Gilbert White, who leaded the UNP report, that the most effective approach to minimize flood damages was via land-use planning to avoid increasing exposure (14), the Flood Insurance Act of 1968 included requirements for participating local governments to prevent further development in floodplains (but unfortunately narrowly defined floodplains as lands that would be inundated by the 1percent flood) (15). Similarly, after the 1993 Mississippi

\footnotetext{
${ }^{a}$ In this paper we use catchment (British English), and watershed (more frequently used in American English) as synonyms for river basin. In British English watershed is more narrowly defined as the line separating two river basins.
}

River floods, the Interagency Floodplain Management Review Committee (1994) concluded that at-risk residents should be relocated in lieu of building more structural controls. However, it has proved difficult to implement these policies because of the disconnection with land-use decisions, which are made at the local level.

With an estimated 100,000 local agencies dealing with water issues and 300 state-level agencies in the US, many with narrowly-defined and sometimes conflicting missions, the US has suffered from a lack of coordination among policies and between policy and implementation with respect to water supply, water quality, and flood related issues (11). The problem is exemplified by local land-use agencies permitting residential developments within designated flood bypasses that are integral components of the federal flood control system on the Mississippi River (17).

Clearly the federal government plays an important role in many aspects of water management in the US, particularly through flood management and water supply projects undertaken by the US Army Corps of Engineers, the US Bureau of Reclamation, the Tennessee Valley Authority, as well as through regulatory and grant programs administered by the US Environmental Protection Agency, the US Department of Agriculture, and Department of Commerce, including regulatory roles derived from the Endangered Species Act (e.g., National Marine Fisheries Service, US Fish and Wildlife Service). However, most legal authority and responsibility for water management lies at the state and local levels (18). IWRM has influenced approaches to water management in a number of states (5), but California has gone further than most in formally promoting the practice of IWRM through state grant programs.

In 2002, the California State Legislature created the Integrated Regional Water Management program $(\text { IRWM })^{\mathrm{b}}$, designed to encourage local water agencies to collaborate with one another to develop regional-level water management plans that integrate all aspects of water management. The program emerged out of a recognition that amidst growing water demands and an increasingly uncertain climate, infrastructure-based strategies could no longer be relied upon to meet water needs, and "integrated" strategies addressing multiple dimensions of water management were essential. The program's creators were also influenced by IWRM principles, emphasizing the importance of holistic management at the catchment scale, and the need to engage a broad range of stakeholders in the process (19). The IWRM program also represented an effort to overcome the long-standing fragmentation of water management responsibilities in California, where over 1,000 special districts, cities and counties hold authority over various aspects of water supply, irrigation,

\footnotetext{
b Note that California's program is abbreviated IRWM, while the broader concept of integrated water resources management is referred to as IWRM.
} 
sanitation, and flood management (20). In particular, flood management and water supply activities have long been managed through separate agencies and processes. In addition, building effective linkages between land use activities and water planning has been an on-going struggle in California (21).

The 2002 IRWM Planning Act established a process whereby local agencies could form a region and jointly prepare an integrated plan for managing their water resources, referred to as an IRWM plan. With such a plan in place, the region was eligible to receive funding to implement IRWM plans, through grants financed by state bonds passed 2002-2014 and administered by the California Department of Water Resources (DWR). Access to these grant funds provided the incentive for local agencies to participate and form IRWM regions. DWR encouraged regions to form along catchment boundaries, but in keeping with California's longstanding tradition of local control over water resources, program requirements allowed local agencies to selforganize around their preferred regional boundaries. By 2012, 48 IRWM regions had been created, covering 87 percent of the state's area and ranging in size from 680 to over 50,000 square kilometers (22). About a quarter of all regions follow catchment boundaries, but most are formed along a combination of catchment, groundwater, or jurisdictional lines (19). Grant program requirements encourage diverse participation, and in fact require that regions reach out to a list of thirteen specific types of stakeholders. In a sample of 19 IRWM regions across the state, cities, counties and agencies responsible for municipal water supply were the most frequent participants. Non-governmental organizations focused on the environment or equity issues participated in high numbers. However, far fewer agencies with flood or stormwater management responsibilities were involved (19). While representatives of counties and cities with land use authority are involved in the IRWM process, the specific individuals attending IRWM meetings are not always those with a role in land use planning.

The primary tasks of participants in IRWM regions are to develop an integrated plan for water management in the region and undertake projects to implement it. Plans must include a comprehensive overview of the region's water resources, and must identify regional goals for water supply, water quality, flood management, and the environment. Each plan must also include a prioritized list of projects to advance the plan's goals. IRWM regions must then seek funding for project implementation. In order to access IRWM project funds, regions must submit to DWR a single, consolidated grant proposal, usually including multiple projects to be implemented by a different participating agencies. Because the application process is quite complex and labor-intensive, inclusion of projects in a grant proposal is not only determined by whether they have a high priority in the plan, but also by whether the agencies that would implement them have adequate resources to participate in the application process.
The goal of the IRWM program was not simply to provide project funding. Instead, the process of writing IRWM plans and developing joint grant proposals was intended to encourage local agencies and nongovernmental organizations to begin to understand each others needs, identify common priorities, and learn to work with one another. As one state official involved in designing the IRWM program commented, "A big part of this is changing a culture, and how we look at me, my neighbors and my regions, and how to solve problems" (19).

The IRWMPs are funded through a series of statewide general obligation bonds passed between 2002-2014 (Propositions 50 in 2002, 1E and 84 in 2006, and 1 in 2014 ) for a total of $\$ 2.31$ billion, of which $\$ 300$ million was targeted specifically for flood and stormwater management (23).

\subsection{Catalan and California Study Area Descriptions}

The Catalan coastal region around Barcelona, Catalonia, Spain, and the San Francisco Bay region around San Francisco, California, US, are both administrative regions for implementation of IWRM, and both include densely settled coastal and estuarine urban areas and drainages from nearby coast ranges. Both administrative regions exclude large inland river basins that traverse the coastal region but whose inland basins fall in different administrative regions (the Ebro River in Catalonia, the Sacramento-San Joaquin in California). These coastal Catalan and San Francisco Bay regions lend themselves well to comparison by virtue of their similar sizes and populations, similar topography, climate, and consequent nature of the flood hazards, and history of water resources development. However, the regions differ sharply in the institutions and policies in place to implement IWRM and manage flood risk (Table 1).

\section{Catalan River Basin District, Catalonia, Spain (EU)}

The Regional Government, and in particular the Catalan Water Agency (ACA) has full authority on water management (Legislative Decree 3/2003 of 4 November 2003) for the Catalan River Basin District. It comprises an area of $16,428 \mathrm{~km}^{2}$ and includes 11 small relatively small river basins draining the coastal ranges and debouching into the Mediterranean. From the French boarder south, these are the Rivers Muga, Fluvià, Ter, Daró, Tordera, Besòs, Llobregat, Foix, Gaià, Francolí, and Riudecanyes (24). This area represents only $52 \%$ of the territory of Catalonia, but because it encompasses Barcelona and other coastal cities, it supports 7 million inhabitants ( $92 \%$ of the Catalan population). Urban and industrial uses represent $65 \%$ of water consumption, with agriculture accounting for the rest. The occupation of flood prone areas with new development along the coast has increased dramatically in Catalonia, especially during the second half of the 20th century (25), with 
development most rapid leading up to the economic crisis of $2008(26,27)$.

\section{San Francisco Bay Area Catchment, California (US)}

The San Francisco Bay is an estuary, which receives runoff from the Sacramento-San Joaquin Rivers, as well as smaller coastal river draining the coastal ranges. The administrative region encompasses the catchments of streams and rivers draining into three distinct "bays" within the estuary (San Francisco, San Pablo, and Suisun Bays), as well as catchments draining directly into the Pacific Ocean immediately north (Tomales-Drakes Bay) and south (San Francisco Coastal South) (28). The San Francisco Estuary includes part of nine counties, three major metropolitan cities (San Francisco, San Jose, and Oakland), and 101 smaller cities and towns. It is the fifth largest metropolitan area in the United States with a population of over 7.2 million, and ranks as the world's 24th largest economy, fueled in part by high-technology industry in Silicon Valley (28). The area covered by the SFBAIRWMP is $17,770 \mathrm{~km}^{2}$.

As one of the largest wetlands in Mediterraneanclimate California, the region supports a productive yet fragile ecosystem, and is internationally recognized as a biodiversity hotspot, with over 105 animal and plant species designated as threatened or endangered (28). The wetlands that rim the estuary are among the most important coastal wintering and migratory stopover areas for millions of waterfowl and shorebirds traveling along the Pacific Flyway, which extends from Alaska to South America.

\section{Results}

\subsection{IWRM and Flood Risk Management Implementation in the Catalan River Basin District}

The Catalan Water Agency is the competent authority to implement the WFD in the Catalan River Basin District (Table 1). Because flood risk management plans must take into account the entire cycle of flood risk management (Figure 1), including prevention, protection and preparedness, the plan development must include all actors involved in flood management and public participation, who participate in the creation of the plan in a coordinated way, under the leadership of the Water Agency. For prevention measures (land use planning and flood zoning, urban regulations), the main institution is the Directorate General of Territorial and Urban Planning, for flood mitigation (river restoration and flood protection) it is the Water Agency for the inland and transitional waters, for the coastal zone (zona marítimoterrestre) it is the State Directorate General of Coast and Sea Sustainability (the Coastal Demarcation), for emergency response, the Directorate General of Civil Protection and the Meteorological Service, and for postdisaster recovery, two State level institutions: the Insurance Compensation Consortium, a public corporate entity attached to the Ministry of Economy and Competitiveness through the Directorate General of Insurance and Pension Funds, which was created in 1954 and acts as a public insurance for disasters (natural and social) (26), and the State Entity of Agricultural Insurance.

To encourage public participation, the Water Agency identified 5,000 actors involved in water management in the region and invited them to meetings to provide their input into the decision-making process for the measures. The final plan, which takes into account the suggestions of the stakeholders, was available online for a 3-month comment period, and the final documents (including public comments) are publicly available on the website of the Catalan Water Agency (Water Agency).

The measures included in the plan are based on a previous risk analysis at a catchment scale. The risk analysis was undertaken in discrete steps, following requirements of the Floods Directive. First (in 2011), the Agency identified fifteen areas of river and floodplain (about $47 \mathrm{~km}$ in length) and 28 coastal areas with potentially significant flood risk, based on existing data and historical flood maps (29). Second (in 2013), the Agency created multiple detailed flood hazard and flood risk maps for each risk area (to be updated every 6 years). These flood hazard maps include 3 scenarios: 10, 100, and 500-year floods (designated as high, medium, and low probability), and for each scenario they show three ranges of water depths: $<40 \mathrm{~cm}, 40-100 \mathrm{~cm}$, and $>100 \mathrm{~cm}$. The Agency also combined maps of flood prone areas (described above) with land-use maps, so the resources vulnerable to flooding (population, economic activities, environment) could be readily determined. For coastal areas, the Coastal Demarcation maps were created for the 100 and 500-year events (medium and low probability), but these maps don't distinguish between different land uses threatened by coastal flooding. The Floods Directive also requires development of maps showing future flood risk, but there is currently inadequate information about future socio-economic and climate changes to create these maps with confidence.

These maps are critical for all the phases of flood risk management, including prohibition of building within the 500 year floodplain, but as elsewhere, enforcing such land-use restrictions has proved challenging in Spain (26). The probability maps are also used by civil protection to define municipalities at medium low, medium, high, and very high risk of flooding. Municipalities with medium or greater flood risk must create local emergency plans. The website of civil protection agency includes these three scenarios, plus the area of the maximum ordinary flood, the 10 and 25 year flood probability maps, and a residual risk map of potentially flooded areas, which are 500 year flood probability maps according to geomorphological features only, i.e. what are would flood if levees failed.

Next step involves creating a flood risk management plan for the Catalan River Basin District by setting up 
objectives and developing a Programme of Measures which has to be implemented through specific actions. The main objective of the plan is to avoid increasing flood risk from existing levels, and to reduce it as much as possible in the areas with potentially significant flood risk. The plan includes measures across the cycle of flood risk management (Figure 1): territorial and urban planning measures for prevention; hydrologic, river restoration, and coastal measures to increase protection; civil protection measures for emergency management and short-term recovery; and measures to promote insurance as a tool to long-term recovery. Each measure is classified as high, medium or low priority taking into account its importance in solving a specific issue, the cost-benefit analysis, the impact in other measures, specially the impact on achieving the environmental water goals of the WFD.

Coordination is a critical aspect of the implementation both the WFD and Floods Directive (Articles 8 and 9), thus this plan not only has to be coordinated with the river basin (water) management plan but also has to be coordinated with other existing plans related to flood management, which are: the general emergency plan of Catalonia, the special emergency plan for flood risk of Catalonia, the local emergency plans, the industries emergency plans, the dams emergency plans, and also other flood-related protocols such as early warning systems.

The budget for the Programme of Measures for the Catalan River Basin District for the second cycle of the implementation of the WDF is 917.89 M€, derived from the regional government $(630,09 \mathrm{M} €)$, water users (208,55 M€), local governments (66,05 M€), and the state $(13,20 \mathrm{M} €)$. This budget is allocated to physical and biological water quality improvement 90.2M€ (10\%), water supply $336.8 \mathrm{M€}(37 \%)$, chemical water quality improvement $392.2 \mathrm{M€}(43 \%)$, flood prevention and protection 97.7 $\mathrm{M} €(10 \%)$, and research innovation and development $1 \mathrm{M} €(0.1 \%)$, the last one paid thought public-private partnership (30). Thus, only $10 \%$ of the total budget is used for flood risk management (Table 1), of which $45 \%$ comes from the Water Agency and the balance from other sources. Nearly $90 \%$ of this goes towards projects related to structural measures and river restoration.

\subsection{The San Francisco Bay Area Integrated Regional Water Management Plan and Flood Risk Management}

In California, the initial goals for the IRWM program were similar to those of the WFD, creating a framework, within which local agencies would integrate programs and projects to protect and enhance regional water supplies, to improve water supply reliability and efficiency, water quality, groundwater quantity and quality, ecosystem and catchment stewardship, and meet the needs of disadvantaged communities $(31,32)$. However, the definition of the regions was left up to the local agencies and stakeholders who chose to participate. The intent was that the regional boundaries would normally correspond to catchment boundaries, but this was up to the local leadership. There was no requirement for local involvement, only the incentive of funding available to self-organized regions. The voluntary character of the initiative allowed local leadership to decide their jurisdictional boundaries, their regional goals, and their governance structure, i.e., the composition of the management group, stakeholders and public involvement (33). As a result, each of the 48 IRWM regions adopting a different approach to IWRM, and to dealing with floods within that context.

The development of the San Francisco Bay Area Integrated Regional Water Management Plan (SFBAIRWMP) was initiated in 2004, when 19 water agencies and local governments signed a memorandum of understanding to work together in response to the state's new IRWM program. An initial plan was produced in 2006, which was revised and updated in 2013. This process has been governed by a Coordinating Committee, which includes two representatives each of agencies involved in the following four "functional areas" of water management: water supply/quality, wastewater/recycled water, flood and stormwater management, and catchment/ecosystem protection. This structure reflects the fact that prior to the IRWM process, water supply had already organized themselves into several networks, one focused on water supply and quality issues (the Bay Area Water Supply and Conservation Agency), and wastewater and sanitation (the Bay Area Clean Water Agencies). Agencies involved in flood management and ecosystem protection had not been formally organized, but the need to represent these interests in the IRWM Coordinating Committee led to the Bay Area Flood Protection Agencies Association (BAFPA). The catchment protection functional area has been led by an informal network of public and non-profit agencies.

While the Coordinating Committee is relatively small, IRWM program guidelines required each region to conduct extensive outreach in the development of IRWM plans, particularly for the 2013 update. Coordinating Committee members, with the help of consultants, hosted sub-regional meetings to discuss water management needs and project ideas, and held numerous public meetings. The resulting 2013 plan is a 1000-page document including a detailed description of the Bay Area catchment area, a discussion of specific water management goals, objectives and strategies, and a prioritized list of 315 projects to meet regional needs (28). The on-going work of the Bay Area IRWM region is to seek funding to undertake these projects, through the IRWM funding process as well as other avenues.

Thus, Region's stakeholder engagement involved a diverse group of water supply, water quality, wastewater, stormwater, flood control, catchment, municipal, environmental, and regulatory groups. This included representatives from federal, state, and local water resource and regulatory agencies, non-governmental 
organizations - in particular those NGOs that represented disadvantaged communities, and the general public. The stakeholder engagement activities were used to inform, educate, and engage constituents throughout the entire Bay Area. Specifically, they were designed to provide the opportunity for people with different levels of knowledge, interest, resources and capacities to help shape the IRWMP.

However, with respect to flood management, representation was more limited (Table 1). Local governments, which are in charge of land use planning (prevention) were involved to some extent, as were flood control agencies (protection), but there was no involvement by representatives of emergency management and recovery, such as the Federal Emergency Management Agency (FEMA) or insurance companies, nor the US Army Corps of Engineers, a big role player in flood management in the US. One possible reason for the lack of participation was that these entities would be unlikely to receive funding from the grant programs, and thus lacked motivation to invest staff time, already committed to funded projects.

In contrast to the Catalan River District plan, the SFBAIRWMP did not include a specific plan for floods (6). However, in compliance with state-mandated requirements, the SFBAIRWMP included flood management as one of its five "over-arching goals":

- Promote environmental, economic and social sustainability

- Improve water supply reliability and quality

- Protect and improve watershed health and function and Bay water quality

- Improve regional flood management

- Create, protect, enhance and maintain environmental resources and habitats.

For the flood management goal, the SFBAIRWMP included six "basic strategies" for flood management:

- Integrated Flood Management and Land Use

- Leverage Natural Watershed Features

- Adopt a "Best Mix" of Structural and Nonstructural Approaches

- Implement Regional Flood Management at a System Scale

- Promote Multiple Benefits

- Implement Multiple-Hazard Management

Once the overarching goals and the basic strategies were developed the Coordinating Committee held an open "call for projects" to identify potential projects that supported IRWMP implementation and promote its goals and objectives. A review and ranking process was developed by the Plan Update Team and approved by the Coordinating Committee. The goal expressly established by the Coordinating Committee was to develop a process, from submittal through prioritization that was transparent, replicable and consistent. Projects then went through a subregional screening for inclusion in the IRWMP. Projects on the Active List were reviewed, scored and ranked with the highest ranking projects receiving funding.

Although the IRWP plans were initially to include groundwater, in anticipation of a groundwater bill in the state legislature, the SFBAIRWMP was not coordinated with groundwater management plans, but with legislative approval of the Sustainable Groundwater Act (SGMA) in 2015 (34), the IRWMP plans should logically coordinate with the SGMA-required groundwater plans.

The SFBAIRWMP was not coordinated with the "Bay Area Plan", which seeks to concentrate development to make transit more efficient in the interests of more sustainable cities, nor with the general plans of the cities and counties (which have the power to approve new developments). Ironically, the transit-oriented focus of the Bay Area Plan creates incentives to concentrate new development at transit hubs, many of which are on floodplains and highly vulnerable to flooding. Thus, the land-use priorities advanced in the name of one socially desirable objective (increased use of public transit and reduced reliance on automobiles) run against the efforts to minimize flood risk.

As of 2016, the San Francisco Bay region received nearly $\$ 238$ million (from bond funding) for projects identified in the IRWM (28). The percentage of this funding invested in flood related projects is not summarized in the SFBAIRWMP, nor is it readily apparent from summary tables listing projects, as many project titles are not specific regarding actions to be taken (e.g., "Corte Madera Creek Watershed - Fairfax Creek Improvement Project"), and to determine the nature of the project would require researching individual project descriptions. However, based on the project titles, approximately 58 of the over 315 projects funded appear to be related to flood risk management.

\section{Discussion}

While the implementation of IWRM concepts is required in the EU by the WFD, there has been no comparable national-level policy encouraging IWRM in the US for three decades. The State of California has tried to put IWRM concepts into practice with the implementation of the IRWM initiative of 2002. However, participation is incomplete, and some Federal agencies, whose role would seem to be essential, have not participated. The use of river basin catchment boundaries for the California program is good, in that it encourages catchment-scale perspectives, but the program of measures adopted is not the result of a systematic, basinscale prioritization, but is rather a collection of multiple projects. Individually these projects may have great merit, but they are not necessarily coordinated for synergistic effect (6).

The regional government of Catalonia, led by the Water Agency, has attempted to integrate all relevant national and regional laws, to coordinate all the different institutions in charge of flood risk management, and to 
develop a plan with active public participation. The SFBAIRWMP was the product of a massive organizational effort, with outreach to hundreds of water agencies and related institutions in region. However, not all of them participated in the plan because of its voluntary character. That makes extremely challenging to do an integrated flood risk management if not all components of the flood risk cycle are represented. For example, FEMA did not actively participate, even though it has a critically important role for planning because it creates the maps and for emergency management. Likewise, neither the US Army Corps of Engineers nor insurance companies played an active role, despite their important roles in flood risk management in the US.

The selection of measures included in the Catalan plan is based on a previous risk analysis at a catchment scale and the mapping of the areas at potential significant risk of flooding. The flood hazard and risk maps are the cornerstones of flood management strategies, since they are used by planning authorities to define flood zoning, and for civil protection to prepare emergency plans. The plan integrates measures for all the phases of the flood risk management cycle and describes how the budget will be shared between the different institutions prioritizing the critical actions to be implemented. Furthermore, the plan is coordinated with the general water plan and with all the flood emergency plans and other protocols such as early warning systems.

The SFBAIRWMP is a collection of projects, some of which are related to floods. Not all the phases of flood risk management are represented by these projects, and there are no projects related to emergency management and recovery. Furthermore, the projects selected were not based on any risk analysis at the catchment scale.

\section{Conclusions}

We examined two attempts in implement IWRM under two different legal and institutional frameworks (California and Catalonia), with very different results (6). In Europe, there is a top-down approach with a common obligatory policy framework specific for floods under the Floods Directive, with a common goal and a common unit of management, the river basin. It defines a 3-step approach for the implementation: risk assessment, mapping and planning. It also specifies that it has to include the whole risk management cycle and makes emphasis on the coordination. This, and the fact that in Catalonia the process was led by a single water agency, resulted in a more integrated flood risk plan from the perspective of IWRM.

The institutional setting is much more complex in California, with thousands of water agencies, and overlapping and often conflicting authorities and missions of federal, state, and local agencies. One clearly positive outcome of the IRWM planning process is that people that had never talked to each other before now know each other and talk. California's IRWM program is a voluntary bottom-up approach and each region decides the jurisdictional boundary, the regional goals, and the governance structure and the approach to select measures (projects). That has resulted in 48 regions with 48 different approaches to deal with floods. Furthermore, the fact that the program is voluntary means that not all the institutions in charge of flood management are participating - a challenging context in which to attempt integrated flood risk management. Moreover, the flood risk management projects funded were not selected based on a prior risk assessment analysis at a river basin scale, so it's impossible to judge the real priority of the projects funded. Although the IRWM process has been beneficial, in practice, at a regional level the flood management approach included in the plan is far from being "integrated". At least it's a start, a step towards integrated flood risk management.

\section{Acknowledgements}

This paper is based on the article "Governing for integrated water and flood risk management: Comparing approaches in Spain and California" currently in review.

\section{References}

1. Biswas AK (2004) Integrated Water Resources Management: A Reassessment: A Water Forum Contribution. Water Int. 29(2):248-56.

2. Lenton R, Muller M (2009) Integrated water resources management in practice: Better water management for development. London: Sterling, VA: Global Water Partnership/Earthscan

3. GWP (Global Water Partnership) (2014) What is IWRM? [Internet]. Available from:

http://www.gwp.org/en/The-Challenge/What-isIWRM/

4. Molle F (2009) River-basin planning and management: The social life of a concept. Geoforum 40(3):484-94.

5. AWRA (American Water Resources Association) (2012) Case studies in integrated water resources management: From local stewardship to national vision [Internet]. AWRA Policy Committee; Available from: http://www.awra.org/policy/policy-statementsIWRM.html

6. Serra-Llobet A, Conrad E, Schaefer K (in review) Governing for integrated water and flood risk management: Comparing approaches in Spain and California. Water.

7. Kaika M (2003) The Water Framework Directive: A new Directive for a changing social, political and economic European framework. Eur Plan Stud. 13(3):299-316. 
8. EU (European Union) (2007) Directive

2007/60/EC of the European Parliament and of the Council of 23 October 2007 on the assessment and management of flood risks. Official Journal on 6 November 2007, page 27.

9. DG Environment (2016) The EU Floods Directive [Internet]. Available from:

http://ec.europa.eu/environment/water/flood_risk/li nks.htm\#fundinglinks

10. WRC (Water Resources Council) (1968) The nation's water resources: the first assessment of the Water Resources Council. Washington DC: US Government Printing Office

11. Dworsky LB, Allee DJ, North RM (1991) Water resources planning and management in the United States federal system: long term assessment and intergovernmental issues. Nat Resour J. 34:475547.

12. US EPA (US Environmental Protection Agency). The watershed approach [Internet]. Undated. Available from: https://www.epa.gov/pollutedrunoff-nonpoint-source-pollution/watershedapproach

13. Duram L, Brown KG (1999) Insights and Applications Assessing Public Participation in U.S. Watershed Planning Initiatives. Soc Nat Resour. 12(5).

14. White GF (1945) Human adjustments to floods: a geographical approach to the flood problem in the United States. University of Chicago

15. Eisenstain W, Kondolf M, Cain J (2007) ReEnvisioning the Delta: Alternative futures for the heart of California. Berkeley, California: Institute of Urban and Regional Development, University of California, Berkeley

16. Federal Interagency Floodplain Management Task Force. A unified national program for floodplain management (1994) Transmitted to the US Congress by President Bill Clinton, March 6, 1995

17. Lopez-Llompart P, Kondolf GM (2016) Encroachments in floodways of the Mississippi River and Tributaries Project. Nat Hazards 81(1):513-42.

18. Huffman JL (2008) The Federal Role in Water Resource Management. NYU Environ Law J. 17(1).

19. Conrad E (2015) Bridging the hierarchical and collaborative divide: Learning in California's Integrated Regional Water Management Process. University of California, Berkeley
20. Hundley, Jr. N (2001) The great thirst: Californians and water - A history. Berkeley, CA: University of California Press

21. DWR (Department of Water Resources) (2014) California water plan Update 2013 (Bulletin 16003). Sacramento, CA: California Natural Resources Agency

22. WEF (Water Education Foundation) (2013) Layperson's guide to integrated regional water management. Sacramento, CA

23. DWR (Department of Water Resources) (2015) IRWM Grant Program Legislation [Internet]. Available from: http://www.water.ca.gov/irwm/grants/legislation.cf $\mathrm{m}$

24. ACA (Agència Catalana de l'Aigua) (2009) Pla de gestió de l'aigua de Catalunya. Document en informació pública [Internet]. Departament de Medi Ambient i Habitatge. Generalitat de Catalunya. Available from: https://acaweb.gencat.cat/aca/documents/ca/planificacio/pla_ gestio_Catalunya/pla_de_gestio_COMPLET.pdf

25. Martí-Llambrich C (2005) La transformació del paisatge litoral de la Costa Brava: Anàlisi de l'evolució (1956-2003), diagnosi de l'estat actual i prognosi de futur. [Girona]: Universitat de Girona

26. Olcina J, Sauri D, Hernández M, Ribas A (2016) Flood policy in Spain: a review for the period 1983-2013. Disaster Prev Manag Int J. 25(1):4158.

27. Pérez-Morales A, Gil-Guirado S, Olcina-Cantos J. (2015) Housing bubbles and the increase of flood exposure. Failures in flood risk management on the Spanish south-eastern coast (1975-2013): Housing bubbles and increase of flood risk in Spain. J Flood Risk Manag. n/a-n/a.

28. SFBAIRWMP (San Francisco Bay Area Integrated Regional Water Management Plan) (2013) San Francisco Bay Area Integrated Regional Water Management Plan

29. ACA (Agència Catalana de l'Aigua) (2015) Proposta de pla de gestió del risc d'inundació del districte de conca fluvial de Catalunya (20162021). Barcelona: Departament de Territori i Sostenibilitat - Departament d'Interior. Generalitat de Catalunya. p. 119

30. ACA (Agència Catalana de l'Aigua) (2015) Pla de gestió del discticte conca fluvial de Catalunya i programa de mesures (2016-2021). Document síntesi. Barcelona: Departament de Territori i Sostenibilitat. Generalitat de Catalunya. p. 42. 
31. California Legislature. Senate Bill 1672 [Internet]. 2002. Available from:

ftp://www.leginfo.ca.gov/pub/0102/bill/sen/sb_16511700/sb_1672_bill_20020921_chaptered.html, accessed 3/10/2015

32. DWR (California Department of Water Resources) (2009) California Water Plan Update 2009: Integrated Water Management (Bulletin 160-09) [Internet]. Available from: http://www.waterplan.water.ca.gov/cwpu2009/in dex.cfm

33. SFBAIRWMP (San Francisco Bay Area Integrated Regional Water Management Plan) (2006) Integration White Paper for the San Francisco Bay Area Integrated Regional Water Management Plan

34. Leahy TC (2016) Desperate Times Call for Sensible Measures: The Making of the California Sustainable Groundwater Management Act. Gold Gate Univ Law J [Internet]. Available from: http://digitalcommons.law.ggu.edu/gguelj/vol9/iss1 14 
Table 1. Characteristics of the two case studies: the Catalan Rive Basin District and the San Francisco Bay Area Region (6).

\begin{tabular}{|c|c|c|c|c|}
\hline & $\begin{array}{l}\text { Catalan River Basin District } \\
\text { (Catalonia, Spain) }\end{array}$ & $\begin{array}{l}\text { San Francisco Bay Area Catchment } \\
\text { (California, US) }\end{array}$ \\
\hline \multicolumn{3}{|c|}{ Overarching program } & $\begin{array}{l}\text { EU - Water Framework Directive } \\
(2000) \\
\text { EU - Floods Directive (2007) } \\
\text { Top-down approach, obligatory }\end{array}$ & $\begin{array}{l}\text { DWR - Integrated Regional Water } \\
\text { Management Program (2002) } \\
\text { Bottom-up approach, voluntary }\end{array}$ \\
\hline \multicolumn{3}{|c|}{ Boundaries (area) } & $\begin{array}{l}\text { Catchment boundary }\left(16,428 \mathrm{~km}^{2}\right) \\
11 \text { sub-catchments } \\
\text { Existing boundaries for water } \\
\text { management since } 1929\end{array}$ & $\begin{array}{l}\text { Catchment boundary }\left(17,770 \mathrm{~km}^{2}\right) \\
6 \text { sub-catchments } \\
\text { New boundaries for water management } \\
\text { since } 2006\end{array}$ \\
\hline \multicolumn{3}{|c|}{ Population } & $\sim 7$ million & $\begin{array}{l}\sim 7 \text { million } \\
\end{array}$ \\
\hline \multirow[t]{12}{*}{ Plans } & \multicolumn{2}{|l|}{ General water plan } & $\begin{array}{l}\text { River Basin Management Plan } \\
\text { (536 pages + annexes) } \\
\text { Leading institution: Water Agency } \\
\text { General goal from the WFD Directive: } \\
\text { - Good ecological status of all waters } \\
\text { by } 2015\end{array}$ & $\begin{array}{l}\text { Integrated Regional Water Management } \\
\text { Plan (963 pages) } \\
\text { Leading institution: water agencies } \\
\text { Regional goals for the San Francisco Bay } \\
\text { Area region: } \\
\text { - Promote environmental, economic and } \\
\text { social sustainability } \\
\text { - Improve water supply reliability and } \\
\text { quality } \\
\text { - Protect and improve catchment health } \\
\text { and function and Bay water quality } \\
\text { - Improve regional flood management } \\
\text { - Create, protect, enhance and maintain } \\
\text { environmental resources and habitats. }\end{array}$ \\
\hline & \multicolumn{2}{|c|}{$\begin{array}{l}\text { Specific plan for floods (Integrated flood risk } \\
\text { management plan) }\end{array}$} & $\begin{array}{l}\text { Required: River Basin Flood Risk } \\
\text { Management Plan } \\
\text { (119 pages + annexes) } \\
\text { General goal from the FD Directive: } \\
\text { - To reduce and manage the risks that } \\
\text { floods pose to human health, the } \\
\text { environment, cultural heritage and } \\
\text { economic activity (FD) }\end{array}$ & No required \\
\hline & \multirow{4}{*}{$\begin{array}{l}\text { Flood-related } \\
\text { agencies } \\
\text { participating in the } \\
\text { plan }\end{array}$} & Mitigation (Prevention) & Territorial and Urban Planning Dtm & Local Governments \\
\hline & & Mitigation (Protection) & Water Agency & Flood Control Agencies (no USACE) \\
\hline & & Emergency & Civil Protection & $\begin{array}{l}\text { Emergency phase is not included in } \\
\text { plan }\end{array}$ \\
\hline & & Recovery & $\begin{array}{l}\text { Civil Protection, } \\
\text { Insurance Compensation Consortium } \\
\text { and ENESA }\end{array}$ & Recovery phase is not included in plan \\
\hline & \multirow{5}{*}{$\begin{array}{l}\text { Flood-related } \\
\text { measures/projects } \\
\text { included in the } \\
\text { plan }\end{array}$} & $\begin{array}{l}\text { Risk-based analysis at a } \\
\text { catchment scale } \\
\text { (Characterization) }\end{array}$ & $\begin{array}{l}\text { Required: } \\
\text { - Preliminary risk assessment } \\
\text { - Flood hazard and risk mapping }\end{array}$ & No required \\
\hline & & Mitigation (Prevention) & yes & yes \\
\hline & & Mitigation (Protection) & yes & yes \\
\hline & & Emergency & yes & no \\
\hline & & Recovery & yes & no \\
\hline & \multicolumn{2}{|l|}{ Budget } & $\begin{array}{l}917 \mathrm{M} € \text { for } 6 \text { years }(2015-2021) \\
10 \% \text { for flood projects }(97 \mathrm{M} €)\end{array}$ & $\begin{array}{l}\$ \$ 238 \text { million (2004 - 2016; } \\
\text { additional funding may follow) }\end{array}$ \\
\hline
\end{tabular}


Figure 1. The flood risk management cycle (6).

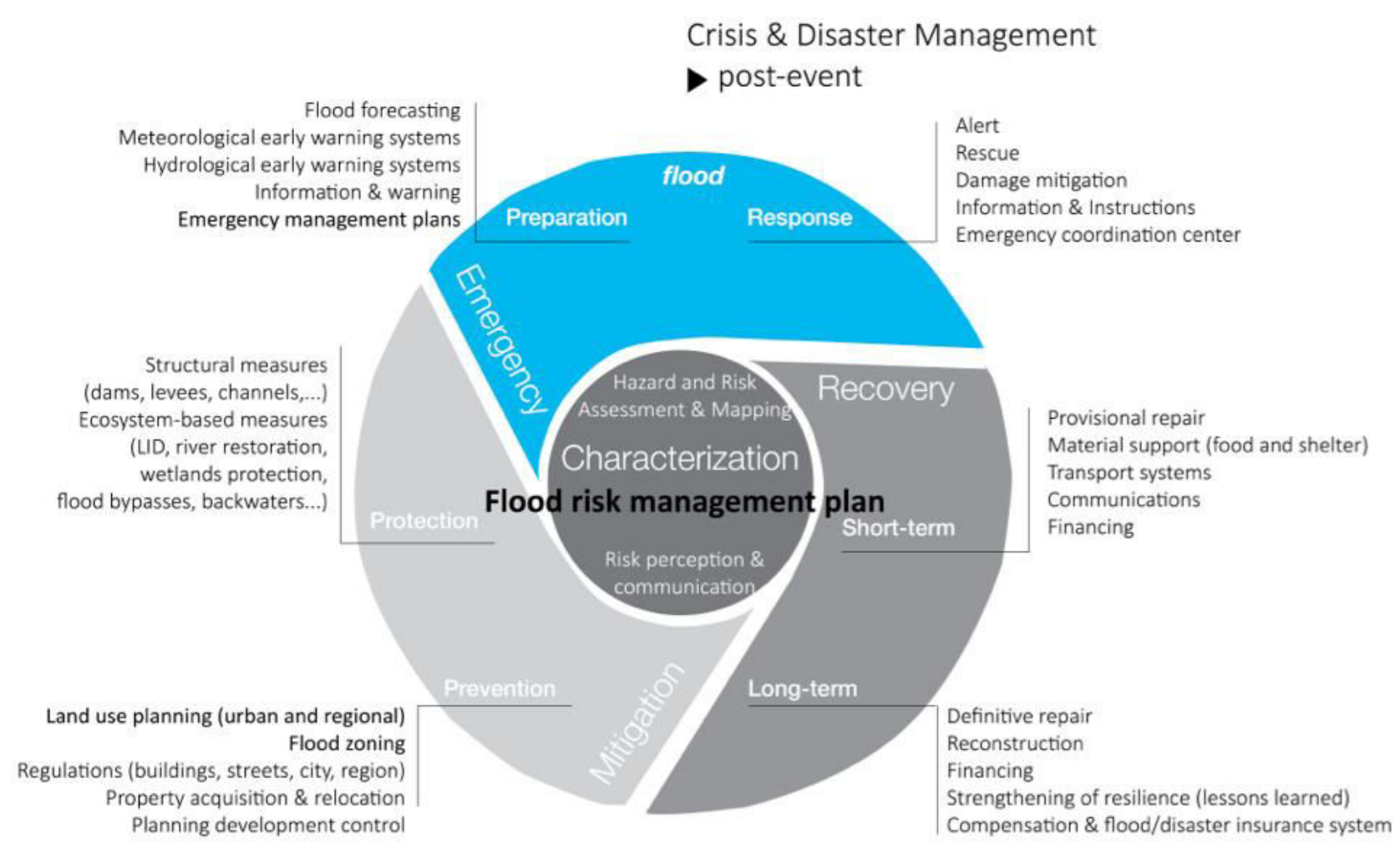

\section{Risk Management \\ pre-event}

